YАK $347.77 / .78$

ББК 67.404 .3

DOI 10.22394/1682-2358-2020-6-103-110

S.N. Mayorov, Leadins Specialist of the Legal Department of LLC "Jewels of Yakutia" (email: clawhands12@gmail.com)

V.V. Levochko, Candidate of Sciences (Law), Senior Lecturer of the Civil Law and Procedure Department, Ammosov North-Eastern Federal University

\section{LEGAL NATURE OF THE WEBSITE DEVELOPMENT CONTRACT AS A RESULT OF INTELLECTUAL ACTIVITY}

Scientific views of civil scientists and the judicial practice regarding the subject matter of a website development contract. Special attention is paid to the features of a website as a composite and complex result of intellectual activity.

Key words and word-combinations: composite work, exclusive right to work, mixed contract.
C.H. Майоров, ведущий спешиалист юридического отдела ООО "Арагоченности Якутии" (email: clawhands12@gmail.com)

B.B. Мебочко, кандидат юридических наук, стариий преподаватель кафедрь гражданского права и прочесса СеВеро-Восточного федерального университета имени М.К. Аммосова

(email: heartval@inbox.ru)

\section{ПРАВОВАЯ ПРИРОАА АОГОВОРА НА РАЗРАБОТКУ ИНТЕРНЕТ-САЙТА КАК РЕЗУ $\Lambda$ ТАТА

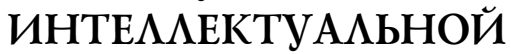 АЕЯТЕАЬНОСТИ}

\begin{abstract}
Аннотация. Исследуются научные представления ученых-цивилистов, а также судебная практика о предмете договора на разработку интернет-сайта. Особое внимание уделяется признакам интернет-сайта как составного и сложного результата интеллектуальной деятельности.

Ключевые слова и словосочетания: составное произведение, исключительное право на произведение, смешанный договор.
\end{abstract}

B глобальная информационная сеть «Интернет», явцяется оАним из слеАствий построения информационного общества, характеризующегося стремительным развитием информационных и телекоммуникационных технологий и распространением их влияния на все аспекты жиз- 
недеятельности человечества. С масштабным внедрением технологий в современном обществе возникают новые соџиальные отношения, а уже сушествовавшие подверглись изменениям.

В законодательстве Российской Федерации не предусмотрены специальные нормы, регулирующие договорные отношения, возникающие по поводу разработки, регистрации и технической подАержки интернет-сайтов. В настоящее время обязательственные отношения, возникающие из договора на разработку интернет-сайта, регламентируются общими нормами гражданского права о договоре и об обязательствах. К трактовке спещиальных норм об отдельных видах обязательств в научной китературе (подрядных правоотношений, оказании ускуг, Аоговоров авторского заказа или смешанного договора) единый подход отсутствует.

В судебной практике также не сформулировано общего мнения, при юридической квалификации такого договора характера, используются разАичные подходы. В связи с этим вопрос о правовой природе указанного Аоговора явмяется открытым. Основным критерием, который способствовал бы правильной квалификации договора, по мнению А.Р. Муратовой и А.М. Багаутдиновой, является его предмет [1] .

Предмет договора на разработку интернет-сайта можно определить как выполнение исполнитемем за плату по согласованному техническому заданию заказчика комплекса организационных, технических и иных мероприятий, направленных на создание интернет-сайта, а также передачу интернет-сайта вместе с искиючительным правом (в полном объеме) на определенный объект заказчику. Разработка интернет-сайта включает несколько этапов: веб-дизайн, то есть создание шаблонов страниц сайта; верстку, или создание гипертекстовых страниц; веб-программирование, или установку и настройку системы управления контентом; регистрацию доменного имени, приобретение хостинга и размешение на них интернет-сайта.

В зависимости от сложности разрабатываемого проекта, поставленных цемей, задач и ожидаемого результата характеристики различных стадий могут существенно отличаться друг от Аруга, а некоторые стадии отсутствовать. Между тем вопрос правовой природы договора напрямую зависит от понятия и правового режима интернет-сайта как объекта.

Отметим, что в 2012 г., с внесением изменений в Федеральный закон от 27 июмя 2006 г. № 149-Ф3 «Об информации, информационных технологиях и о защите информации», законодательно закреплена дефиниция интернет-сайта. Так, согласно п. 13 ст. 2 Ф3-149 данного Закона сайт в Интернете - это «совокупность программ для электронных вычислительных машин и иной информации, содержащейся в информационной системе, Аоступ к которой обеспечивается посредством информационно-телекоммуникационной сети "Интернет" по доменным именам и

104 Bulletin of the Volga Region Institute of Administration • 2020. Vol. 20. № 6 
(или) по сетевым аАресам, позволяющим идентифицировать сайты в сети “Интернет”».

Тем не менее ученые-цивилисты предлагают иные определения. П.В. Бабарыкин считает, что «под сайтом Интернет как цифровым произведением понимается объективная форма представления и организации электронных документов и цифровых произведений (например, китературных произведений, фотографий, аудиовизуальных произведений, звукозаписей, программ Амя ЭВМ, баз данных и т.А.), систематизированных таким образом, чтобы эти данные могли быть найдены и обработаны с помощью технологий Интернет» [2, с. 10] .

Подобной позиџии придерживается А.К. Быстров, определяя интернет-сайт как «совокупность выраженных в цифровой форме результатов интемлектуальной деятельностии средств индивидуализации, размещенную автором интернет-сайта, обладателем исключительного права на интернетсайт или уполномоченным им Аиџом в сети "Интернет" таким образом, что к ней имеет Аоступ неограниченный круг Аиџу [3, с. 255].

По мнению А.А. Кравченко, «интернет-сайтом является доступная посреАством сети Интернет совокупность самостоятельных материамов, систематизированных таким образом, чтобы эти материалы могми быть найдены поисковой системой и обработаны с помощью браузера» [4, c. 214].

Очевидно, что интернет-сайт обладает признаками объекта гражданских прав, такими как дискретность (обособленность), юридическая привязанность (указание в нормах права в качестве объекта), системность (имеет общие признаки объекта прав и специальные признаки, относящиеся его к определенному виду объектов гражданских прав).

По своей сущности интернет-сайт - это продукт интемлектуальной и творческой деятельности человека. Интернет-сайт не имеет материальной формы и существует в информационной среде, в связи с чем может быть подвергнут копированию и заимствованию, поэтому как объект гражданских прав явцяется охраняемым результатом интелцектуальной деятельности, чем и определяется спеџифика его гражданско-правового режима.

В научной цитературе и судебной практике распространен подход о признании интернет-сайта составным произведением, преАставцяющим собой по подбору или расположению материалов результат творческого труда. Отметим, в п. 2 ст. 1260 ГК РФ закреплен перечень составных произведений «антологии, энциклопедии, базы данных, интернет-сайта, атмаса или Аругого подобного произведения». Согласно подп. 2 п. 2 ст. 1259 ГК РФ, составные произведения явцяются объектами авторских прав.

Очевидным, является факт, что интернет-сайт имеет эмектронную форму и доступ к нему обеспечивается посреАством Интернета. Исходя из 
этого, приходим к выводу, что наполняемый контент должен быть преАставлен в соответствующей форме, то есть эмектронной, чтобы стать частью составного произведения. Следовательно, полагаем, что при созАании интернет-сайта в качестве контента могут быть задействованы те объекты авторских прав, которые указаны в перечнях п. 1 и 2 ст. 1259 ГК РФ [5].

ОАнако не все перечисленные объекты авторских прав могут быть задействованы в качестве контента для интернет-сайта. А.А. Кравченко разграничивает указанные объекты на группы. К первой группе относятся, те объекты, которые создаются мибо могут быть представлены в электронной форме (Аитературные произведения, фотографические произведения и произведения, полученные способами, аналогичными фотографии и т.А.). Ко второй группе относятся объекты авторских прав, создающиеся в форме аудио- и видеозаписи. Например, созданное в письменной форме Араматическое произведение, преобразуется в видеозапись. Третью группу составляют производные и составные произведения при условии, если их представят в соответствующей форме. В четвертую группу включаются другие произведения при условии, если их представят в соответствующей форме, необходимой дмя ее созерџания в качестве контента интернет-сайта [4].

Таким образом, А.А. Кравченко обусловливает отнесение интернет-сайта к составному произвеАению, преАставляющему собой осуществленный творческий труА миџа, явцяющегося автором, по подбору ици расположению материалов именно в электронной форме. Аанный критерий явцяется уникальной особенностью построения интернет-сайта, поскольку сами нормы статьи предполагают, что Амя формирования обычного составного произведения необходимо только выполнить подбор и расположение материалов таким образом, чтобы оно отвечало изначально поставценным требованиям.

ОАнако существуют сайты, относящиеся к корпоративным, они характеризуются как мокальные, то есть доступные в рамках организации, к ним нет доступа посредством Интернета. Следовательно, в зависимости от цемей назначения интернет-сайты могут быть представлены в форме некоммерческих и коммерческих сайтов.

К некоммерческим сайтам относятся следующие: корпоративный сайт, то есть сайт, необходимый дмя внутриорганизаџионного файлообмена, как правицо, ограниченный цокальным доступом; официальный сайт, цемью которого явмяется ознакомление с информаџией о деятельности миџа, организации мибо государственного органа; информационный портал, џемью которого явмяется информационное обеспечение (например, общеАоступный информационный сайт «Википедия», новостные издания и т.А.).

К коммерческим относятся сайты, основной задачей которых является получение прибыли- это интернет-магазины и различные сервисы (онмайн-кинотеатры). 
Поскольку интернет-сайт состоит из различных эмементов, наА которыми на отдельных этапах работают разные мюди (верстка, веб-дизайн, наполнение контентом), то его следует рассматривать в качестве сложного объекта в соответствии со ст. 1240 ГК РФ. Как указывает Е.А. Суханов, формирование сложных объектов включает в себя творческий труА различных $и ц$, при этом каждое мицо работает над отдельным произведением, которое отправляется на следующий этап работ, при котором уже Аругое мицо создает целый комплексный объект, именуемый сложным объектом. При этом кажАый участник сложного проџесса при создании эмемента сложного объекта своим творческим трудом имеет искиючительное право на произведение [6, с. 731].

В п. 1 ст. 1240 ГК РФ представлен перечень сложных объектов, который вкцючает несколько охраняемых результатов интемлектуальной деятельности. Таковыми могут быть признаны кинофильмы, иные аудиовизуальные произведения, театрально-зрелищные представления, мультимедийные продукты и базы данных. Отметим, что многие исследователи, в частности, А.А. Кравченко и А.К. Быстров, указывают на необходимость включения в перечень интернет-сайтов.

В вопросе о сложности произведения Е.С. Басманова выделяет несколько обязательных признаков, которым должен отвечать подобный объект: наличие в составе объекта нескольких охраняемых результатов интемлектуальной деятельности, разнородных, созданных авторами в сотрудничестве; сложная внутренняя структура объекта. Исходя из этого, можно сАелать вывод, что интернет-сайт следует причислять к сложным объектам, так как отвечает указанным признакам, отмечая при этом, что под разнородностью понимается относимость результатов интемектуальной деятельности к разным категориям охраняемых объектов, а под сотрудничеством - разнородность творческого труда авторов [7, c. 21-22]. К тому же в основу признака сложной внутренней структуры взят критерий системности, то есть взаимосвязанность множества охраняемых результатов интемлектуальной деятельности и их зависимость Аруг от Аруга в составе сложного объекта, а не собирательное множество эмементов как совокупность.

Приведенное мнение, однако, ставит под сомнение выводы А.А. Кравченко, указывающего, что нередко при создании интернет-сайтов в состав общего контента не вкцючаются результаты интеммектуальной деятельности неоднородного характера. Более того, в ст. 1240 ГК РФ не содержится прямого обязательного указания на критерий неоднородности. Автор выводит иные признаки сложного объекта исходя из смысла ст. 1240 ГК РФ:

«1) наличие в составе объекта нескольких, не обязательно разнородных, охраняемых результатов интемлектуальной деятельности; 
2) наличие субъекта - миџо, организовавшее создание сложного объекта, которое получает искмючительное право на произведение на основании договора об отчуждении исключительного права, Аибо получает право использования произведения на основании миџензионного Аоговора;

3) сложный объект Аолжен относиться к одному из объектов, опредеменных в закрытом перечне из кинофильма, иного аудиовизуального произведения, театрально-зрелищного преАставления, мультимедийного проАукта, базы данных» [4] .

Таким образом, интернет-сайт не во всех случаях может рассматриваться как сложное произведение.

Разработаны и подтверждены судебной практикой следующие варианты правовой квалификации договора на разработку интернет-сайта: Аоговор подряда; Аоговор возмездного оказания услуг; Аоговор авторского заказа; смешанный тип договора.

Например, в случае с возмездным оказанием услуг Федеральный арбитражный суд Волго-Вятского округа вынес постановление, в котором квацифицировал договор на разработку интернет-сайта "как Аоговор возмезАного оказания услуг, поскольку его предметом явцяется создание в информационном пространстве файлов веб-сайта, результат работ носит неовеществленный характер» [8].

В случае с договором подряда Федеральный арбитражный суА Поволжского округа вынес постановление от 8 мая 2014 г. по Аелу № А65-8792/2012, в котором, рассматривая с правовой точки зрения интернет-сайт как информаџионный ресурс, пришел к тому, что интернет-сайт явмяется совокупностью информации, которая содержится в той ици иной информационной системе и находится в распоряжении обладателя информации. При этом суд, ссылаясь на такое юридическое свойство информации, как Авуединство информации и ее носителя, указывает на овещественность цифровой информации в сицу того, что она содержится на материальном носителе. Таким образом, по рассматриваемому судом договору на разработку интернет-сайта результатом выполненных работ является созданный интернет-сайт, который должен быть передан на материальном носителе (фмеш-накопитель). Исходя из этого суд квалифицировац рассматриваемые правоотношения как договор подряда, регулируемый п. 1 гл. 37 ГК РФ [9].

В свою очередь, Федеральный арбитражный суд Уральского округа в постановлении пришел к выводу, что рассматриваемые судом договорные правоотношения следует квалифиџировать как смешанный договор возмездного оказания услуг и подряда, поскольку целью правоотношений обеих сторон является создание и получение такого результата интелмектуальной деятельности, как интернет-сайт. При этом при оказании услуги

108 Bulletin of the Volga Region Institute of Administration • 2020. Vol. 20. № 6 
«продается» не результат интемлектуальной деятельности, а деятельность, которая привела к созданию такого результата [10] .

Согласно ОКВЭА Аействия по разработке интернет-сайта отнесены к группе 62.01.11 ускуги по проектированию, разработке информационных технологий дмя прикладных задач и тестированию программного обеспечения.

П.В. Бабарыкин указывает, что в зависимости от жекаемого результата договор на разработку интернет-сайта может включать в себя следующее:

«1) авторский Аоговор на тексты, рисунки, анимаџию, музыку, фильмы, программы, базы данных и другие охраняемые произведения;

2)договор подряда с элементами авторского договора на создание информационного ресурса (интернет-сайта как цифрового произведения) в форме, пригодной амя размещения в сети Интернет;

3) Аоговор на оказание услуг по установке и настройке системы управмения контентом или иных программно-аппаратных комплексов;

4) договор об оказании услуг по регистраџии доменного имени;

5) Аоговор оказания ускуг хостинга» [2].

Отсутствие единого мнения ученых о правовой природе, равно как и отсутствие единого варианта правовой квалификации таких договорных правоотношений, в настоящее время явцяется проблемой.

Итак, договор на разработку интернет-сайта по правовой природе явмяется смешанным. С одной стороны, цель правоотношений - получение результата работы, с другой - проџесс разработки и результат труда ведется в информаџионном пространстве и не имеет материальной формы, в связи с чем возникают исключительные права на нематериальный результат: сложное составное произведение интернет-сайт. С развитием информационных технологий в настоящее время не требуются материальные носители дмя передачи информации, она осуществляется непосредственно в самом информаџионном пространстве. Тем не менее отсутствие овеществленной природы интернет-сайта не может свидетельствовать о том, что он не является результатом подряда, права на которые могут отчуждаться. В отличие от услуг в подряде важен именно результат, а не процесс деятельности.

Аоговор авторского заказа предполагает, что исполнителем явцяется физическое киџо. Между тем разработкой сайтов занимаются субъекты предпринимательства, юридические миџа, а в работе над интернет-сайтом участвуют целые комлективы в рамках своих трудовых отношений с юридическим лицом - исполнителем по договору. Итогом деятельности трудового комлектива становится составное сложное произведение - интернет-сайт, исключительные права на который возникают у юридического миџа с момента создания. Таким образом, договор разработки интернет-сайта юридическим миџом нельзя квалифиџировать как договор авторского заказа. 
ОАнако не исключается возможность разработки интернет-сайта оАним физическим киџом - индивидуальным предпринимателем, а также комлективом физических миџ - авторов. В данных случаях возникающие правоотношения целиком подпадают под положения договора авторского заказа, с последующим отчуждением исключительного права.

В зависимости от поставленных задач оказываются дополнительные усцуги по регистраџии доменного имени, услуги хостинга и т.А. САедует учитывать, что перечисленные услуги явцяются дополнительными и могут быть не вкмючены в преАмет договора.

В заключение можно сделать вывод, что наиболее оптимально выдецить два варианта договора на разработку интернет-сайта в зависимости от субъектного состава: смешанный договор с элементами подряда и Аоговора отчуждения исключительных прав в случае, если исполнителем по Аоговору является юридическое миџо; договор авторского заказа, если исполнителем по Аоговору является индивидуальный преАприниматель, мибо физические миџа. КажАый из указанных Аоговоров может Аополнительно вкцючать обязательства по предоставлению услуг регистраџии Аоменного имени, хостинга, поддержания и обновления сайта и других услуг, связанных с функционированием составного сложного произведения в Интернете.

\section{Библиографический список}

1. Муратова А.Р., Багаутдинова А.М. К вопросу о правовой природе договора на разработку веб-сайта // Вестник Костромского государственного университета. 2018. Т. 24, № 4. С. 290-295.

2. Бабарыкин П.В. Гражданско-правовое регулирование создания и использования сайтов сети Интернет: дис.... канд. юрид. Наук. СПб. 2005.

3. Быстров A.К. Интернет-сайт и доменное имя как объекты гражданских прав в системе отношений по использованию сети Интернет: дис. ... канд. юрид. наук. М., 2016.

4. Кравченко А.А. Правовой режим интернет-сайт как комплексного объекта права интеллектуальной собственности: дис. ... канд. юрид. наук. М., 2016.

5. Гражданский кодекс Российской Федерации (часть четвертая) от 18 дек. 2006 г. № 230-Ф3 (в ред. от 30 окт. 2020 г.) // С3 РФ. 2006. № 52, ч. 1. Ст. 5496.

6. Российское гражданское право: в 2 т. Т. 1: Общая часть. Вещное право. Наследственное право. Интеллектуальные права. Личные неимущественные права: учебник / под ред. Е.А. Суханова. М., 2011.

7. Басманова Е.С. Интернет-сайт как объект имущественных прав: дис. ... канд. юрид. наук. М., 2010.

8. Постановление ФАС Волго-Вятского округа от 18 апр. 2012 г. по делу № А439577/2011 URL: http://www.consultant.ru/

9. Постановление ФАС Поволжского округа от 14 марта 2013 г. по делу № А658792/2012. URL: http://www.consultant.ru/

10. Постановление ФАС Уральского округа от 22 апр. 2010 г. № Ф09-3004/10-С2 по делу № A76-20390/2009-2-856. URL: http://www.consultant.ru/ 